\title{
GABA Signaling and Neuroactive Steroids in Adrenal Medullary Chromaffin Cells
}

\author{
Keita Harada ${ }^{1}$, Hidetada Matsuoka ${ }^{1}$, Hiroaki Fujihara ${ }^{2}$, Yoichi Ueta ${ }^{2}$, Yuchio Yanagawa ${ }^{3}$ \\ and Masumi Inoue ${ }^{1 *}$
}

${ }^{1}$ Department of Cell and Systems Physiology, University of Occupational and Environmental Health School of Medicine, Kitakyushu, Japan, ${ }^{2}$ Department of Physiology, University of Occupational and Environmental Health School of Medicine, Kitakyushu, Japan, ${ }^{3}$ Department of Genetic and Behavioral Neuroscience, Gunma University Graduate School of Medicine, Maebashi, Japan

\section{OPEN ACCESS}

Edited by: Egidio D'Angelo,

University of Pavia, Italy

Reviewed by:

Enrico Cherubini,

International School for Advanced

Studies, Italy

Andrea Barberis,

Fondazione Istituto Italiano di

Tecnologia, Italy

${ }^{*}$ Correspondence: Masumi Inoue

minoue@med.uoeh-u.ac.jp

Received: 04 June 2015 Accepted: 01 April 2016

Published: 18 April 2016

Citation:

Harada K, Matsuoka H, Fujihara H, Ueta $Y$, Yanagawa $Y$ and Inoue $M$ (2016) GABA Signaling and Neuroactive Steroids in Adrenal Medullary Chromaffin Cells.

Front. Cell. Neurosci. 10:100. doi: 10.3389/fncel.2016.00100
Gamma-aminobutyric acid (GABA) is produced not only in the brain, but also in endocrine cells by the two isoforms of glutamic acid decarboxylase (GAD), GAD65 and GAD67. In rat adrenal medullary chromaffin cells only GAD67 is expressed, and GABA is stored in large dense core vesicles (LDCVs), but not synaptic-like microvesicles (SLMVs). The $\alpha 3 \beta 2 / 3 \gamma 2$ complex represents the majority of $\mathrm{GABA}_{\mathrm{A}}$ receptors expressed in rat and guinea pig chromaffin cells, whereas PC12 cells, an immortalized rat chromaffin cell line, express the $\alpha 1$ subunit as well as the $\alpha 3$. The expression of $\alpha 3$, but not $\alpha 1$, in PC12 cells is enhanced by glucocorticoid activity, which may be mediated by both the mineralocorticoid receptor (MR) and the glucocorticoid receptor (GR). GABA has two actions mediated by $\mathrm{GABA}_{A}$ receptors in chromaffin cells: it induces catecholamine secretion by itself and produces an inhibition of synaptically evoked secretion by a shunt effect. Allopregnanolone, a neuroactive steroid which is secreted from the adrenal cortex, produces a marked facilitation of $\mathrm{GABA}_{\mathrm{A}}$ receptor channel activity. Since there are no GABAergic nerve fibers in the adrenal medulla, GABA may function as a para/autocrine factor in the chromaffin cells. This function of GABA may be facilitated by expression of the immature isoforms of GAD and GABA $A$ receptors and the lack of expression of plasma membrane GABA transporters (GATs). In this review, we will consider how the para/autocrine function of GABA is achieved, focusing on the structural and molecular mechanisms for GABA signaling.

Keywords: GABA, adrenal chromaffin cell, PC12 cell, neuroactive steroid, paracrine, GAD67, GABA $A_{A}$ receptors, immature subunit

GABA is synthesized not only in the brain, but also in peripheral tissues and organs, such as the pancreas (Okada et al., 1976) and the adrenal medulla. The presence of GABA in the bovine adrenal medulla was first reported in 1984 (Kataoka et al., 1984), and thereafter GABA's actions in adrenal medullary chromaffin cells of dogs (Kataoka et al., 1986), cattle (Peters et al., 1989), rats (Matsuoka et al., 2008), and guinea pigs (Inoue et al., 2013) in vivo and/or in vitro have been functionally explored.

Compared to the adrenal medulla, there is ample research on GABA in the brain where it is the major inhibitory neurotransmitter. This review is focused on the functions of GABA in the adrenal chromaffin cells, but a brief recapitulation of GABA signaling in the brain will help our understanding of GABA functions in the adrenal medulla. Neuronal GABA is synthesized from glutamic acid by glutamic acid decarboxylase (GAD), an enzyme that is encoded by two different 
genes, GAD2 (GAD65) and GAD1 (GAD67; Obata, 2013). GAD exists as a homo- or heterodimer of GAD65 and GAD67. GAD65 is mainly present in the nerve terminal, whereas GAD67 is diffusely distributed in the cell body as well as nerve terminals (Pinal and Tobin, 1998; Soghomonian and Martin, 1998; Obata, 2013). GAD67 plays the major role for GABA production in the embryonic brain (Asada et al., 1997), whereas the contribution of GAD65 begins to increase after birth. In the adult $50-70 \%$ of the total GABA in the brain is produced by GAD65 and the remaining GABA by GAD67 (Stork et al., 2000). Thus, both isoforms are involved in production of GABA in adult brain (Pinal and Tobin, 1998; Obata, 2013). The development of GAD65 appears to parallel that of inhibitory neuronal transmission in the brain (Greif et al., 1992). The subtypes of $\mathrm{GABA}_{\mathrm{A}}$ receptors also change during the brain development (Laurie et al., 1992; Ortinski et al., 2004). These results suggest that the function of GABA in the embryonic brain differs from its role as a neurotransmitter in the mature brain (Ben-Ari et al., 2007; Pallotto and Deprez, 2014). Thus, it is likely that GABAergic transmission has multiple functions which may change during brain development. However, how the expression of GABA signaling molecules coordinately changes remains to be fully elucidated (Succol et al., 2012).

In this review, we will consider the functions of GABA in the adrenal medulla while referring to GABA signaling in neurons and other endocrine cells. Special focus will be placed on the structural and molecular mechanisms for GABA actions in chromaffin cells. Overall the data indicate that the expression of GABA signaling molecules in adrenal chromaffin cells is finely tuned for GABA to function as a para/autocrine factor to modulate catecholamine secretion.

\section{MORPHOLOGY OF GABA SIGNALING IN THE ADRENAL MEDULLA}

\section{Localization of GABA}

When the localization of GABA was examined in bovine, dog and mouse adrenal medullae with immune-labeling approaches, GAD- and/or GABA-like immunoreactivities (IRs) were detected in chromaffin cells and nerve fiber-like structures (Kataoka et al., 1984, 1986; Iwasa et al., 1998). Previously, retrograde tracing had revealed that several areas in the brain and the spinal cord had materials that were retrogradely transported from the rat adrenal medulla (Mohamed et al., 1988; Coupland et al., 1989). Thus, it is possible that neurons in such areas send GABAergic nerve fibers to adrenal chromaffin cells. However, this idea has not been supported by pharmacological analyses of neuronal transmission. Fast synaptic currents evoked in slices of the rat adrenal medulla by field stimulation were completely suppressed by application of hexamethonium, a nicotinic ACh receptor blocker (Barbara and Takeda, 1996; Kajiwara et al., 1997). These electrophysiological findings would negate the possible innervation by GABAergic fibers in the adrenal medulla. This notion is further supported by immunostaining for GAD and vesicular GABA transporter

A
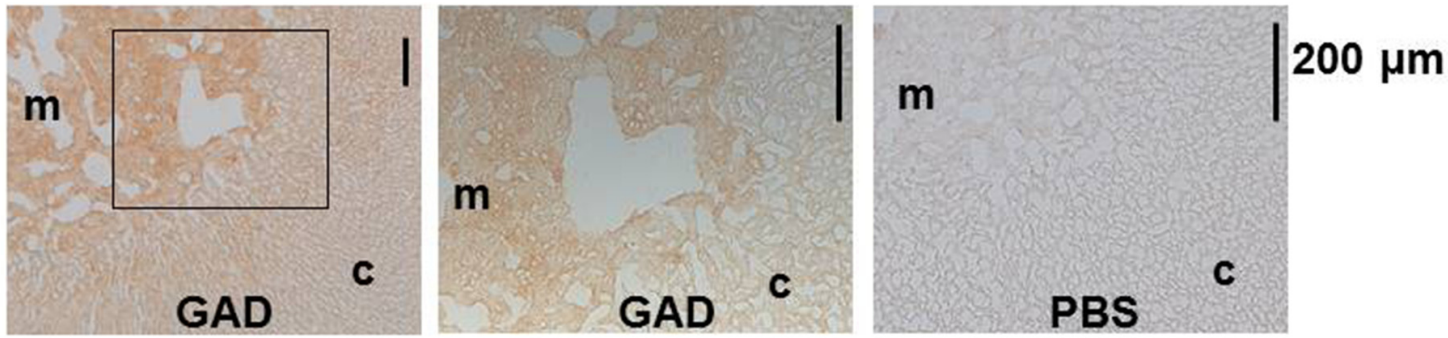

B
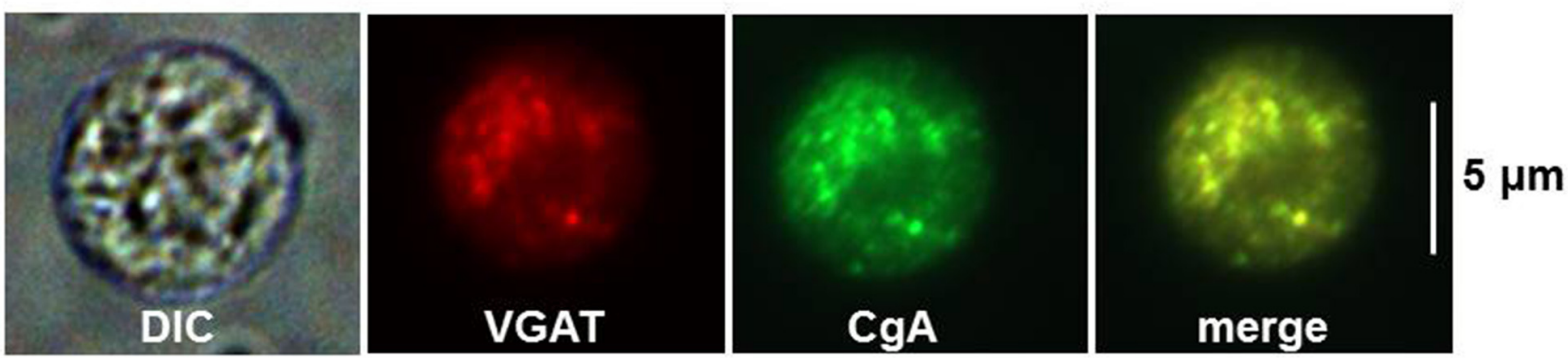

FIGURE 1 | Immunostaining for glutamic acid decarboxylase (GAD) and vesicular GABA transporter (VGAT) in rat adrenal medullary chromaffin cells. (A) Immunohistochemistry for GAD in rat adrenal gland. Sections were incubated overnight in PBS with (GAD) or without (PBS) rabbit anti-GAD antibody (Ab). The bound $\mathrm{Ab}$ was detected with the indirect immunoperoxidase method. The middle panel represents an enlargement of the area indicated by the square in the left panel. (B) Immunocytochemistry for VGAT in a dissociated rat adrenal medullary cell. The adrenal medulla was treated with collagenase and then cells were mechanically dissociated with needles. The cells were treated overnight with rabbit anti-VGAT Ab and goat anti-chromogranin A (CgA) Ab and then with secondary Abs conjugated with Alexa 488 and Alexa 546. Images from left to right represent differential interference contrast (DIC), rhodamine-like, FITC-like, and merge of the second and the third. (A,B) Are reproduced from Matsuoka et al. (2008). 
(VGAT), which is involved in the uptake of GABA into vesicles. GAD proteins were recognized in the rat adrenal medulla by immunoblotting, and GAD-like IR was present in rat adrenal chromaffin cells but not in fiber-like structures (Figure 1). Furthermore, the mRNA for GAD67, but not GAD65, was detected in rat adrenal medullae by RT-PCR analysis (Matsuoka et al., 2008; Inoue et al., 2010), suggesting that the GAD activity was not in nerve terminals. VGAT was also detected in rat adrenal chromaffin cells at the mRNA and protein levels (Matsuoka et al., 2008). The immunostaining for GAD and VGAT unambiguously indicate that GABA is synthesized in chromaffin cells, but not nerve fibers, in the adrenal medulla of at least rats.

\section{GABA-Storing Secretory Vesicles}

Chromaffin cells have two kinds of secretory vesicles: one is the large dense core vesicles (LDCVs) or chromaffin granules with a mean diameter of $356 \mathrm{~nm}$ (Plattner et al., 1997), where catecholamines are stored together with chromogranins and ATP. The second is synaptic-like microvesicles (SLMVs) with a mean diameter of $90 \mathrm{~nm}$ (Plattner et al., 1997), which correspond to synaptic vesicles in the nerve terminal (ThomasReetz and De Camilli, 1994). There is morphological and biochemical evidence that GABA is stored in LDCVs, but not in SLMVs, in rat and bovine adrenal chromaffin cells (Inoue et al., 2010). First, VGAT was co-localized with chromogranin, a marker protein of LDCVs (Figure 1B), but not synaptophysin, an integral protein of SLMVs (Navone et al., 1986). Also, fractionation analysis of homogenates of the bovine adrenal medulla revealed that VGAT was detected in the fractions of high density, where dopamine $\beta$-hydroxylase, an enzyme involved in the synthesis of noradrenaline from dopamine, was enriched, whereas synaptophysin was enriched in fractions of intermediate density (Harada et al., 2010). When the homogenate was centrifuged and divided into supernatent and pellet fractions and then the pellet was subjected to sucrose density fractionation, GABA was recovered together with catecholamines in high density fractions. Furthermore, when a fusion protein of green fluorescent protein with VGAT (GFP-VGAT) was exogenously expressed in the PC12 cell, an immortalized cell line of rat adrenal chromaffin cells, it was localized in organelles immunopositive for chromogranin. In contrast, a GFP-vesicular acetylcholine transporter fusion protein (GFP-VAChT) was mainly present in organelles that were immunopositive for synaptophysin, suggesting that GFP-VGAT and GFP-VAChT were located in LDCVs and SLMVs, respectively (Harada et al., 2010).

The two kinds of secretory vesicles also occur in pancreatic $\beta$ cells (Reetz et al., 1991) where insulin and GABA are produced. Insulin is stored in LDCVs. In contrast to chromaffin cells, GABA is stored in both SLMVs and in LDCVs in $\beta$ cells of at least rats (Reetz et al., 1991; Gammelsaeter et al., 2004): gold particles for GABA and VGAT were concentrated much more in SLMVs rather than in LDCVs.

\section{Functions of LDCVs and SLMVs}

Whether GABA is stored in LDCV or SLMV is important for its physiological role. Secretion mediated by SLMVs occurs rapidly compared with that of LDCVs (Kasai, 1999), for example in PC12 cells the time constants for exocytosis differ by $10 \times$ or more between SLMVs and LDCVs. This difference between SLMVs and LDCVs may be accounted for by the synaptotagmin isoforms mainly present in these two vesicles. The $\mathrm{Ca}^{2+}$ sensitivity and kinetics of $\mathrm{Ca}^{2+}$ interaction of synptotagmin differ among isoforms: $\mathrm{Ca}^{2+}$ affinity of synaptotagmin 7 is much higher than that of synaptotagmin 1 (Wang et al., 2005), and the kinetics of the former is slower than that of the latter (Hui et al., 2005). Thus, the presence of synptotagmin 1 as the main isoform in synaptic vesicles in the nerve terminal (Geppert et al., 1994) would allow action potentials arriving in the nerve terminal to trigger a rapid secretion of neurotransmitters, so that neurotransmission can occur with a delay of less than $1 \mathrm{~ms}$ (Johnston and Wu, 1995; Minneci et al., 2011). As in other secretory cells, the main isoforms of synaptotagmins present in LDCV and SLMV in chromaffin cells are different. The major isoform present in LDCVs is synptotagmin 7, whereas that in SLMVs is synptotagmin 1 although synaptotagmin 1 is found in LDCV (Matsuoka et al., 2011).

As mentioned previously, a part of the GABA molecules in pancreatic $\beta$ cells are likely stored in SLMVs, and GABA has been shown to inhibit glucagon secretion from pancreatic $\alpha$ cells (Rorsman et al., 1989; Xu et al., 2006). This GABA-mediated inhibition of glucagon secretion may occur under conditions where $\beta$ cells are strongly excited, so that synaptotagmin 1 in SLMVs is activated with the consequent release of GABA. That is, in the islets of Langerhans GABA released from $\beta$ cells may act in a paracrine manner to reduce glucagon release from $\alpha$ cells. In contrast to $\beta$ cells, in chromaffin cells GABA is stored in LDCV rather than SLMV. The storage of GABA in LDCVs suggests that GABA plays a modulatory role for secretion of catecholamines. As the amount of secreted catecholamine increases, that of GABA also increases and so acts to reduce high levels of secretion (see "Dual Action of GABA" Section below).

\section{GABA $_{A}$ RECEPTORS IN CHROMAFFIN CELLS}

Receptors for GABA comprise ionotropic $\mathrm{GABA}_{\mathrm{A}}$ receptors containing a directly-gated ion channel and metabotropic $\mathrm{GABA}_{B}$ receptors (Inoue et al., 1985). Bovine chromaffin cells in culture have been shown to express $G_{A B A}$ receptors by functional analyses (Castro et al., 1989). However, rat chromaffin cells failed to respond to baclofen, a $G A B A_{B}$ receptor agonist, and GABA-induced currents were suppressed by bicuculline, a $\mathrm{GABA}_{\mathrm{A}}$ receptor antagonist (Matsuoka et al., 2008), indicating the expression of $\mathrm{GABA}_{\mathrm{A}}$ receptors, but not $G_{A B A}$ receptors. Therefore, only $G_{A B A}$ receptors will be discussed here.

\section{Subunit Composition of GABA Receptors}

$\mathrm{GABA}_{\mathrm{A}}$ receptors are a pentamer of $\alpha(\alpha 1$ to $\alpha 6)$ and $\beta$ ( $\beta 1$ to $\beta 3$ ) subunits, with one or more $\gamma(\gamma 1$ to $\gamma 3), \rho$ ( $\rho 1$ to $\rho 3), \delta, \varepsilon$, or $\theta$ subunits. The possible combinations of these subunits are enormous, but the actual isoforms 
A

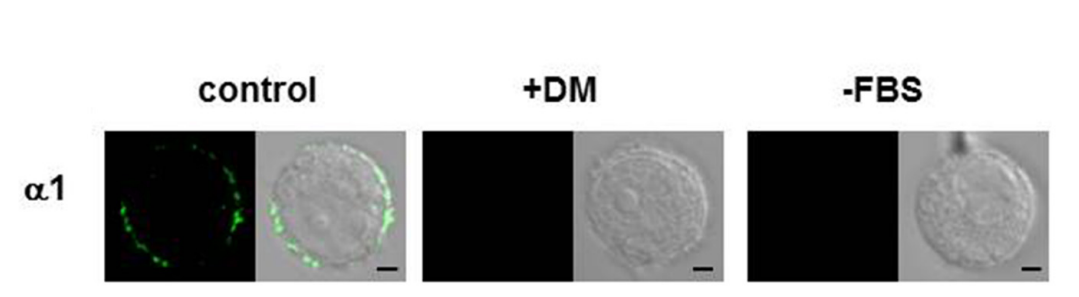

B

$\alpha 3$

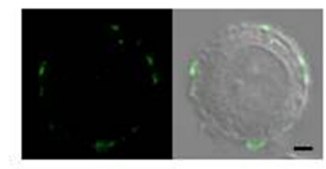

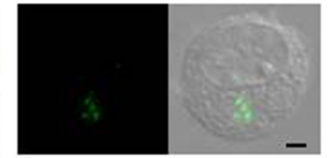

$2 \mu \mathrm{m}$

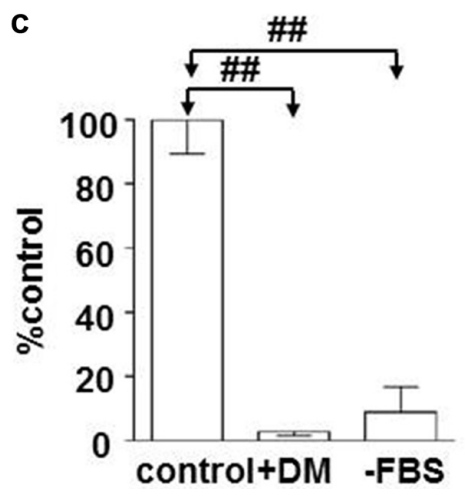

D

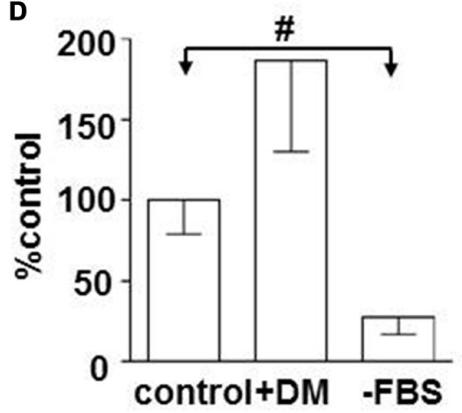

FIGURE 2 | Enhancement of expression of the GABA $\alpha 3$ subunit in PC12 cells by dexamethasone. (A,B) Immunofluorescent staining for $\alpha 1$ and $\alpha 3$ subunits in PC12 cells, respectively. Cells were cultured for 1 week in Dulbecco's modified medium supplemented with 10\% fetal bovine serum (FBS; control), Dulbecco's modified medium with $10 \mu \mathrm{M}$ dexamethasone (+DM), or Dulbecco's modified medium (-FBS). Left and right images represent confocal fluorescent images and merge of fluorescent and DIC images. (C,D) Summaries of $\alpha 1$ - and $\alpha 3$-like immunoreactivities, respectively. The amounts of $\alpha 1$ - and $\alpha 3$-like immunoreactivities were measured by using ImageJ software ( $\mathrm{NIH}$, Bethesda, MD, USA). The amounts of the immunoreactivities in PC12 cells cultured with DM (+DM) and without DM and FBS (-FBS) were expressed as percentages of those in the control PC12 cells, which were measured under the same conditions. The data indicate mean \pm SEM (C, $n=12,12$, and 10 for control, + DM, and -FBS, respectively; D, $n=19,9$, and 10 for control, +DM, and -FBS, respectively). " and ${ }^{\# \#}$ represent statistical significance of $P<0.01$ and $P<0.001$, respectively. (B,D) Are reproduced from Inoue et al. (2013).

of $\mathrm{GABA}_{\mathrm{A}}$ receptors present in the brain are limited (Rudolph and Knoflach, 2011): 60\% of them are the complex of two $\alpha 1$, two $\beta$, and one $\gamma 2$ subunits, and in $20 \%$ of $\mathrm{GABA}_{\mathrm{A}}$ receptors, two molecules of the $\alpha 2, \alpha 3$, or $\alpha 5$ subtype are combined with two $\beta$ and one $\gamma 2$ subunits. In the brain, $\mathrm{GABA}_{\mathrm{A}}$ receptor expression begins early in development (Serafini et al., 1998; Ben-Ari et al., 2007), and their subunit combination changes during development (Laurie et al., 1992; Ortinski et al., 2004). The $\alpha 2$ and $\alpha 3$ subunits are predominantly expressed in the embryonic rat brain, while the $\alpha 1$ subunit becomes predominant during the first 3 weeks of postnatal life (Okada et al., 2000; Bosman et al., 2002; Ehrlich et al., 2013). Because of this developmental change, $\alpha 2$ and $\alpha 3$ are called immature subunits, whereas $\alpha 1$ is a mature subunit. The replacement of $\alpha 2$ or $\alpha 3$ subunits with $\alpha 1$ results in a shortening of the time course of the decay of inhibitory postsynaptic currents, probably because the open time of $\alpha 1$-containing $\mathrm{GABA}_{\mathrm{A}}$ receptors is shorter than that of $\alpha 3$-containing receptors (Mozrzymas et al., 2007). Thus, this replacement leads to increased temporal precision of inhibitory neurotransmission in the brain. It has been suggested that in the embryonic brain GABAergic transmission functions in a more general, volume transmission mode that converts to a more precise, synaptic mode with development (Represa and Ben-Ari, 2005).

In contrast to the mature brain, GABA in the adrenal medulla is not involved in synaptic neurotransmission. The combination of subunits in chromaffin cells may reflect the physiological function which GABA mediates. RT-PCR and immunoblotting of rat adrenal medullae revealed the expression of $\alpha 1$ and $\alpha 3$ subunits (Matsuoka et al., 2008). With immunoprecipitation these subunits were confirmed to be complexed with $\beta 2 / 3$ and $\gamma 2$ or $\delta$ subunits. However, a recent quantitative analysis of protein expression revealed that the $\alpha 3$ subunit is the major $\alpha$ subunit expressed in adrenal medullae of not only rats, but also guinea pigs (Inoue et al., 2013). The enhancement of GABA-induced currents by L-838, 417, an $\alpha 3$-selective benzodiazepine analog, in guinea-pig chromaffin cells supports the dominant expression of $\alpha 3$ and indicates that the $\alpha 3$ subunit is mainly complexed with $\gamma 2$ (Inoue et al., 2013). Furthermore, GABA-induced currents were suppressed by $\mathrm{Zn}^{2+}$ in a dosedependent manner and the inhibition was well described by a rectangular hyperbola, suggesting that $\mathrm{GABA}_{\mathrm{A}}$ receptors in chromaffin cells are homogeneous (Inoue et al., 2013). To summarize, $\mathrm{GABA}_{\mathrm{A}}$ receptors in chromaffin cells are mainly represented by the $\alpha 3 \beta 2 / 3 \gamma 2$ complex. 

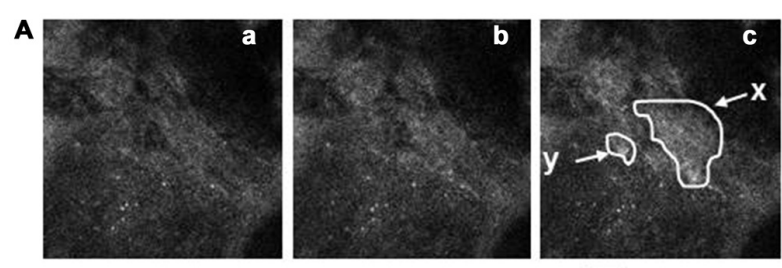

$200 \overline{\mu m}$

B

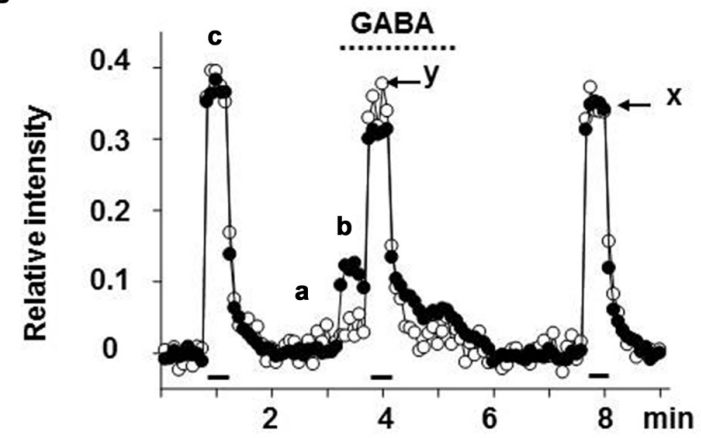

FIGURE 3 | Suppression of the synaptically evoked $\mathrm{Ca}^{2+}$ signal in rat adrenal chromaffin cells by GABA. (A) Confocal images of Fluo-4

fluorescence in rat adrenal medulla. The adrenal gland was retrogradely loaded with Fluo-4 AM, a $\mathrm{Ca}^{2+}$ indicator via the adrenal vein, and then part of the adrenal cortex covering the medulla was removed by microscissors under a stereoscope (Warashina and Inoue, 2012). The adrenal gland was placed between a pair of silver circles for electrical stimulation. Confocal images of FITC-like fluorescence in adrenal chromaffin cells were acquired every $5 \mathrm{~s}$. (B) Relative values of the change in fluorescence intensity are plotted against time. The adrenal gland was retrogradely perfused with saline via the adrenal vein, and $30 \mu \mathrm{M}$ GABA was added to the perfusion solution during the indicated period (dotted line). Nerve fibers were electrically stimulated with $60 \mathrm{~V}$ pulses of $1.5 \mathrm{~ms}$ duration at $10 \mathrm{~Hz}$ for $30 \mathrm{~s}$ (bars). Fluorescence intensities in the areas ( $x$ and $y$ ) indicated in (A) part c were measured and presented as filled $(x)$ and open $(y)$ symbols, respectively. Note that the cells in the region indicated by $y$ showed no response to the application of GABA, whereas those in the region marked $x$ did. After correction for the decline due to photobleaching, the increase in fluorescence intensity was expressed as a fraction of the resting level. The images marked $a, b$, and $c$ in (A) correspond to the points labeled in (B). (A,B) Are reproduced from Matsuoka et al. (2008).

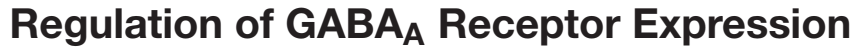

The fact that the $\alpha 3 \beta 2 / 3 \gamma 2$ complex constitutes the majority of $\mathrm{GABA}_{\mathrm{A}}$ receptors means chromaffin cells continue to express immature $\mathrm{GABA}_{\mathrm{A}}$ receptors in adulthood, which raises a question about how the control of subunit expression may differ between adrenal gland and brain. The internal environment drastically changes in the growth process from the prenatal period to the neonate and then juvenile periods. One such change in rats is a decrease in blood glucocorticoid during the first 2 weeks of life (Sapolsky and Meaney, 1986). Early life experience, including impaired maternal care, influences brain development and the expression of $\mathrm{GABA}_{\mathrm{A}}$ receptors in the adulthood (Caldji et al., 1998, 2003), and the blood glucocorticoid concentration increases in rats subjected to maternal deprivation (Chen et al., 2012). These observations suggest that glucocorticoids play an important role for regulation of $\mathrm{GABA}_{\mathrm{A}}$ receptors. To examine the effects of glucocorticoids on the expression of $\mathrm{GABA}_{\mathrm{A}}$ receptors, PC12 cells were used. PC12 cells were found to express $\alpha 1$ as well as $\alpha 3$ subunits, which were mainly present at the cell periphery (Inoue et al., 2013). The expression of both subunits was abolished by removal of serum from the culture medium, but that of $\alpha 3$-but not $\alpha 1$-was restored by addition of the synthetic glucocorticoid dexamethasone (Figure 2), indicating that glucocorticoid activity supports $\alpha 3$ expression. There are two kinds of receptors in the cytosol to which glucocorticoids bind: one is mineralocorticoid receptor (MR); the other is glucocorticoid receptor (GR; de Kloet et al., 2005). The GR and MR function either as a homodimer or heterodimer, and the affinity of MR for cortical steroids is 10-fold higher than that of GR (de Kloet et al., 2005). The expression of $\alpha 3$, but not $\alpha 1$, in PC12 cells was suppressed in a dose-dependent manner by not only mifepristone (Inoue et al., 2013), a specific GR inhibitor (Reul et al., 1990), but also by RU28318 (unpublished observations by KH and MI), a specific MR inhibitor (Ulmann et al., 1985), suggesting the involvement of MR as well as GR. In fact, the expression of MR in PC12 cells has been reported (Goto et al., 2009). Whether MR is involved in the regulation of $\alpha_{3}$ expression in adrenal chromaffin cells or not remains to be explored. One critical difference between adrenal medulla and brain may be the existence of a higher glucocorticoid level in the extracellular space of adrenal medulla (Wurtman, 2002). Thus, based on the fingdings in PC12 cells, glucocorticoids likely preserve $\alpha 3$ expression in adrenal chromaffin cells. Recently, a decrease in intracellular $\mathrm{Cl}^{-}$concentration $\left(\left[\mathrm{Cl}^{-}\right]_{\mathrm{i}}\right)$ has been shown to be involved in the substitution of $\alpha 1$ for $\alpha 3$ (Succol et al., 2012). The value of $\left[\mathrm{Cl}^{-}\right]_{\mathrm{i}}$ in neurons is determined by a balance between $\mathrm{Na}^{+}, \mathrm{K}^{+}, \mathrm{Cl}^{-}$-cotransporter type 1 (NKCC1) and $\mathrm{K}^{+}, \mathrm{Cl}^{-}$-cotransporter type 2 (KCC2), which are responsible for import and export of $\mathrm{Cl}^{-}$, respectively (Kaila et al., 2014). Aldosterone has been reported to enhance NKCC1 activity in vascular smooth muscle cells (Ding et al., 2014) with the consequent increase in $\left[\mathrm{Cl}^{-}\right]_{\mathrm{i}}$ (Davis et al., 1993). These results raise the possibility that glucocorticoids enhance NKCC1 activity in chromaffin cells, thereby preserving $\alpha 3$-containing $\mathrm{GABA}_{\mathrm{A}}$ receptors. A further study will be required to elucidate the molecular mechanism for $\alpha 3$ preservation in chromaffin cells.

\section{EFFECTS OF GABA}

\section{Differences Among Species}

The fact that the expression of $\alpha 3$ depends on glucocorticoid activity in PC12 cells indicates that the subunit composition and/or expression of $\mathrm{GABA}_{\mathrm{A}}$ receptors in cells can be altered in culture. One of the advantages of using acutely dissociated chromaffin cells is that receptors and ion channels in cells can be examined under more physiological conditions compared with cultured cells. The responses of acutely dissociated chromaffin cells to GABA conspicuously differ between rats and guinea pigs. Application of $30 \mu \mathrm{M}$ GABA evoked inward currents in $33 \%$ of rat chromaffin cells examined (Warashina and Inoue, 2012), but in 100\% of guinea-pig 
chromaffin cells (Warashina and Inoue, 2012). In addition, even in responding cells the amplitudes of GABA-induced currents in rat cells were tiny compared with those in guineapigs. Such differences, however, did not occur for nicotineinduced currents. Since the dose response relationship for GABA did not differ noticeably between rat (Matsuoka et al., 2008) and guinea-pig chromaffin cells (Inoue et al., 2013), the subunit composition of $\mathrm{GABA}_{\mathrm{A}}$ receptors in both may be the same, suggesting that the difference in amplitude is the result of different levels of expression. There is a possibility that the difference in the expression level of $\mathrm{GABA}_{\mathrm{A}}$ receptors is related to the humoral environments in rats and guinea pigs. One difference is that the main glucocorticoid in rats and mice is corticosterone, whereas that in guinea pigs and humans is cortisol. The glucocorticoid activity of corticosterone is one-tenth to one-third that of cortisol (Mahgoub et al., 1997). Therefore, corticosterone may not be sufficient to maintain a high level of expression of $\alpha 3$-containing $\mathrm{GABA}_{\mathrm{A}}$ receptors in rat adrenal chromaffin cells.

\section{Dual Action of GABA}

The fact that GABA induces excitation in adrenal chromaffin cells with the consequent secretion of catecholamines has been known since the 1980s. As GABA did not change the percentage of adrenaline in the total catecholamine secreted in perfused rat adrenal glands (Inoue et al., 2010), GABA A receptors are likely to be expressed similarly in adrenaline and noradrenaline cells. This non-selectivity is in contrast with the selective expression of $M_{1}$ muscarinic receptors in adrenaline cells, a muscarinic receptor subtype involved in secretion (Inoue et al., 2010; Harada et al., 2015).
The intracellular concentration of $\mathrm{Cl}^{-}$in rat chromaffin cells was electrophysiologically estimated to be $31 \mathrm{mM}$, as the equilibrium potential for $\mathrm{Cl}^{-}\left(\left[\mathrm{E}_{\mathrm{Cl}}\right]\right)$ is $-38 \mathrm{mV}$ (Matsuoka et al., 2008; Inoue et al., 2010). It is likely that the chloride gradient and $\mathrm{E}_{\mathrm{Cl}}$ in rat chromaffin cells is determined by finely tuned expression and/or function of NKCC1 and KCC2 (Kaila et al., 2014). This value of $\mathrm{E}_{\mathrm{Cl}}$ may allow GABA to have a dual action; GABA by itself induces excitation, but inhibits the much larger excitation resulting from a volley of neuronal inputs. As shown in Figure 3, GABA alone induced a depolarization with the consequent activation of voltage-dependent $\mathrm{Ca}^{2+}$ channels by stimulating $\mathrm{GABA}_{\mathrm{A}}$ receptors, resulting in catecholamine secretion. When the adrenal medulla was electrically stimulated at a high frequency $(5-10 \mathrm{~Hz})$ during $\mathrm{GABA}_{\mathrm{A}}$ receptor stimulation, the total amplitude of $\mathrm{Ca}^{2+}$ signals, which consisted of GABA-induced and synaptically evoked $\mathrm{Ca}^{2+}$ responses, was smaller than that evoked synaptically alone (Figure 3 ). This decrease in the overall $\mathrm{Ca}^{2+}$ signal is ascribed to the fact that the membrane electrical shunt induced by GABA (reversal potential at about $-38 \mathrm{mV}$ ) reduces the depolarization resulting from nerve stimulation and so reduces $\mathrm{Ca}^{2+}$ channel activation.

The $\mathrm{E}_{\mathrm{Cl}}$ in rat chromaffin cells is more negative than the $\mathrm{E}_{\mathrm{Cl}}(-28 \mathrm{mV})$ in cultured bovine chromaffin cells (Xie et al., 2003). This difference might account for the apparent absence of a shunt effect of $\mathrm{GABA}_{\mathrm{A}}$ receptor activation in bovine chromaffin cells: the peak amplitude of nicotineinduced $\mathrm{Ca}^{2+}$ signals was not altered by $\mathrm{GABA}_{\mathrm{A}}$ receptor stimulation, even though GABA alone induced an increase in $\mathrm{Ca}^{2+}$ concentration (Xie et al., 2003). This failure of GABA to suppress the $\mathrm{Ca}^{2+}$ signal may be due to the

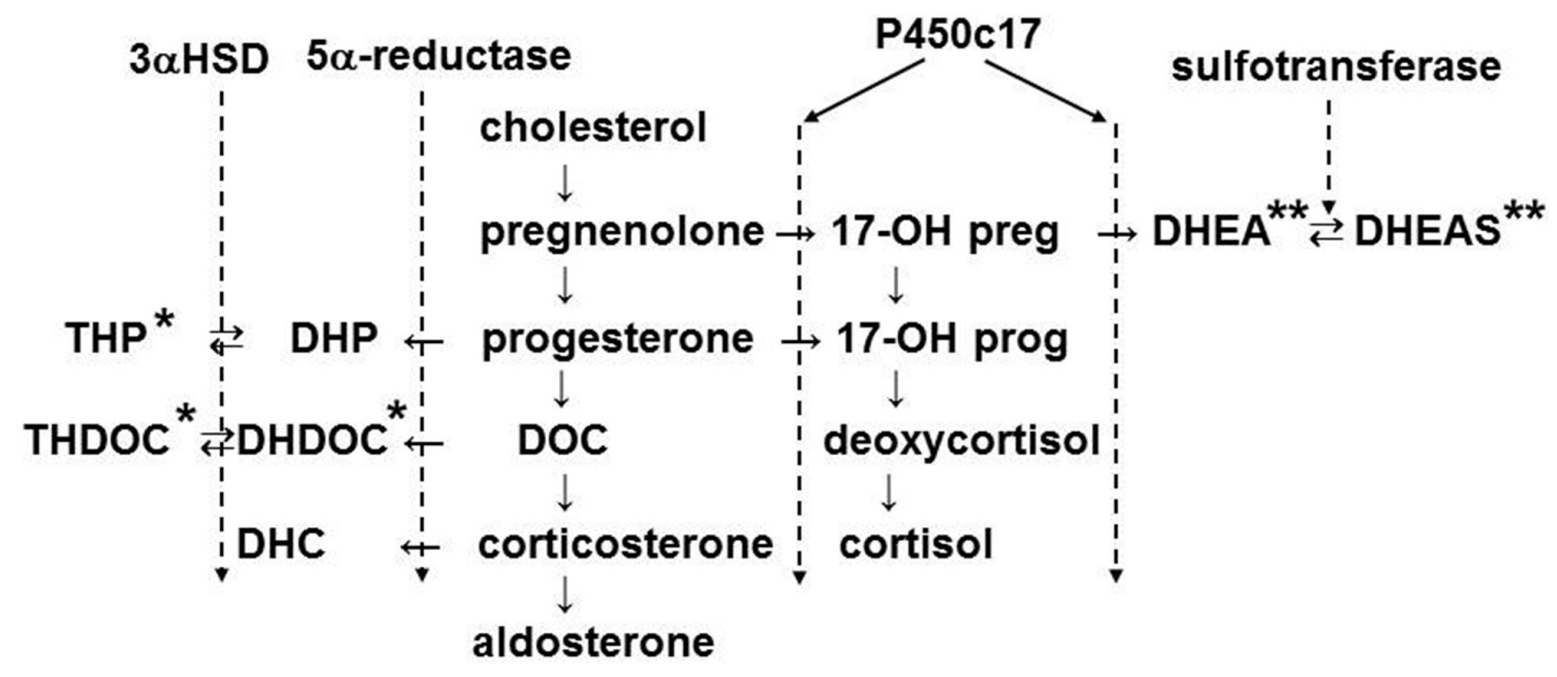

FIGURE 4 | Biosynthetic pathway of adrenal steroids. The enzymes shown mediate the conversion of steroids in the indicated step(s). The names of steroids are abbreviated: THP, $3 \alpha, 5 \alpha$-tetrahydroprogesterone or allopregnanolone; DHP, $5 \alpha$-dihydroprogesterone; THDOC, $3 \alpha, 5 \alpha$-tetrahydrodeoxycorticosterone; $\mathrm{DHDOC}, 5 \alpha$-dehydrodeoxycorticosterone; DHC, dehydrocorticosterone; DOC, 11-deoxycorticosterone; 17-OH preg, 17-OH pregnenolone; 17-OH prog, 17-OH progesterone; DHEA, dehydroepiandrosterone; DHEAS, DHEA sulfate. $3 \alpha H S D$, 3 $\alpha$-hydroxysteroid dehydrogenase. The steroids marked by single and double asterisks are positive and negative allosteric modulators of $\mathrm{GABA}_{\mathrm{A}}$ receptors, respectively. 
$\mathrm{E}_{\mathrm{Cl}}$ of $-28 \mathrm{mV}$, which is likely enough to activate a substantial number of voltage-dependent $\mathrm{Ca}^{2+}$ channels. This more positive value of $\mathrm{E}_{\mathrm{Cl}}$ in bovine chromaffin cells might be due to the maintenance of cells under culture conditions for a few days, which may preferentially facilitate the expression of NKCC1 rather than KCC2 with the consequent increase in $\left[\mathrm{Cl}^{-}\right]_{\mathrm{i}}$.

A possible dual action of GABA in adrenal chromaffin cells could have a significant physiological function. When the live organism is subjected to a stressor, the organism would respond to it with a rapid, nerve evoked secretion of catecholamines from the adrenal medulla, which results in increases in blood glucose and blood flow in the skeletal muscle. However, if a high glucose level is sustained, it would be harmful to the body, resulting in the outbreak or exacerbation of the metabolic syndrome. On the other hand, a low level of blood adrenaline would be beneficial in that it ameliorates the metabolic syndrome by facilitating glucose uptake with the consequent decrease in blood glucose (Ziegler et al., 2012). In this manner, the dual action of GABA might both enhance low levels of release and dampen high levels, and so would contribute to a delicate regulation of catecholamine secretion.

\section{ACTIONS OF NEUROACTIVE STEROIDS}

Neuroactive steroids, such as allopregnanolone, are produced in adrenal glands of mammals including rats (Corpéchot et al., 1993) and humans (Genazzani et al., 1998) and are known to act on $\mathrm{GABA}_{\mathrm{A}}$ receptors (Zhu and Vicini, 1997; Belelli and Lambert, 2005). Therefore, to elucidate the function of GABA signaling in the adrenal medulla, it will be important to take into account the effects of neuroactive steroids. Figure 4 illustrates the biosynthetic pathway for adrenal steroids, in which positive (Lambert et al., 1995; Reddy and Rogawski, 2002) and negative (Park-Chung et al., 1999) allosteric modulators are denoted by single and double asterisks, respectively. The adrenal cortex of rats and mice lacks the expression of P450c17 (Le Goascogne et al., 1991; Figure 4). Therefore, the main glucocorticoid in such rodents is corticosterone, whereas in other mammals including humans it is cortisol. The lack of $\mathrm{P} 450 \mathrm{c} 17$ results in a loss in production of dehydroepiandrosterone (DHEA) and its sulfated form or DHEAS in the adrenal cortex. In rat gonads where $\mathrm{P} 450 \mathrm{c} 17$ is expressed, DHEAS is produced. In contrast, allopregnanolone (THP in Figure 4) is produced in the adrenal glands of rats (Corpéchot et al., 1993) and
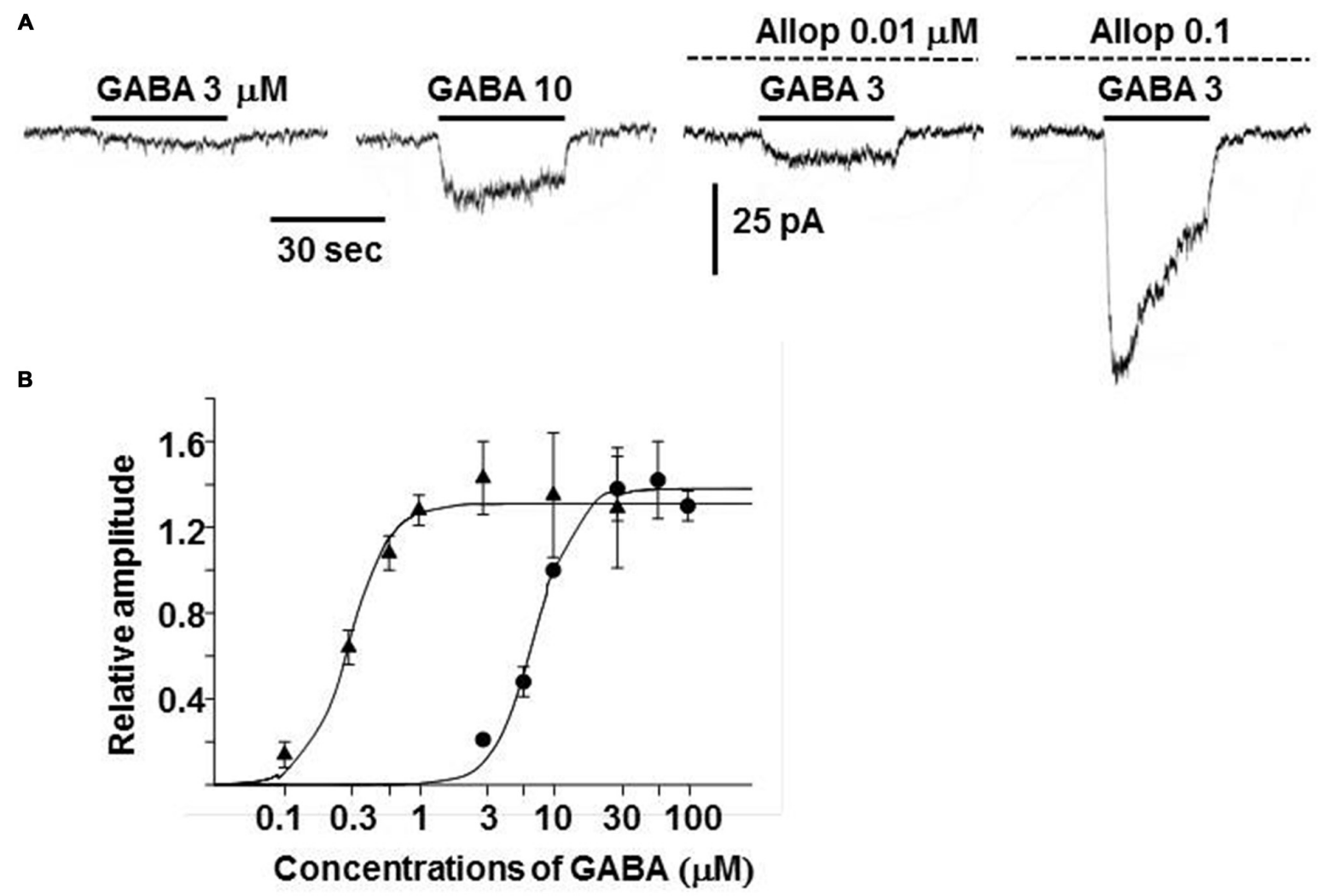

FIGURE 5 | Enhancement of GABA receptor channel activity by allopregnanolone. (A) Whole-cell currents recorded from a dissociated guinea-pig chromaffin cell at $-60 \mathrm{mV}$. The traces were obtained from the same cell. GABA at 3 or $10 \mu \mathrm{M}$ was bath applied during the indicated period (bars) in the absence and presence of 0.01 or $0.1 \mu \mathrm{M}$ allopregnanolone (interrupted lines). (B) Dose-response curves for GABA-induced currents at the plateau level in the absence (•) and presence $(\mathbf{\Lambda})$ of $0.1 \mu \mathrm{M}$ allopregnanolone. The lines show fits of logistic equations with $I_{\mathrm{Max}} \mathrm{S}$ of 1.38 and 1.31 , slope factors of 2.88 and 2.83 , and $\mathrm{EC}_{50} \mathrm{~S}$ of 7.2 and $0.3 \mu \mathrm{M}$ in the absence and presence of allopregnanolone, respectively. Plateau amplitudes of GABA-induced currents are expressed as fractions of those of $10 \mu \mathrm{M}$ GABA currents in the same cells. The data represent mean \pm SEM. (A,B) Are reproduced from Inoue et al. (2013). 


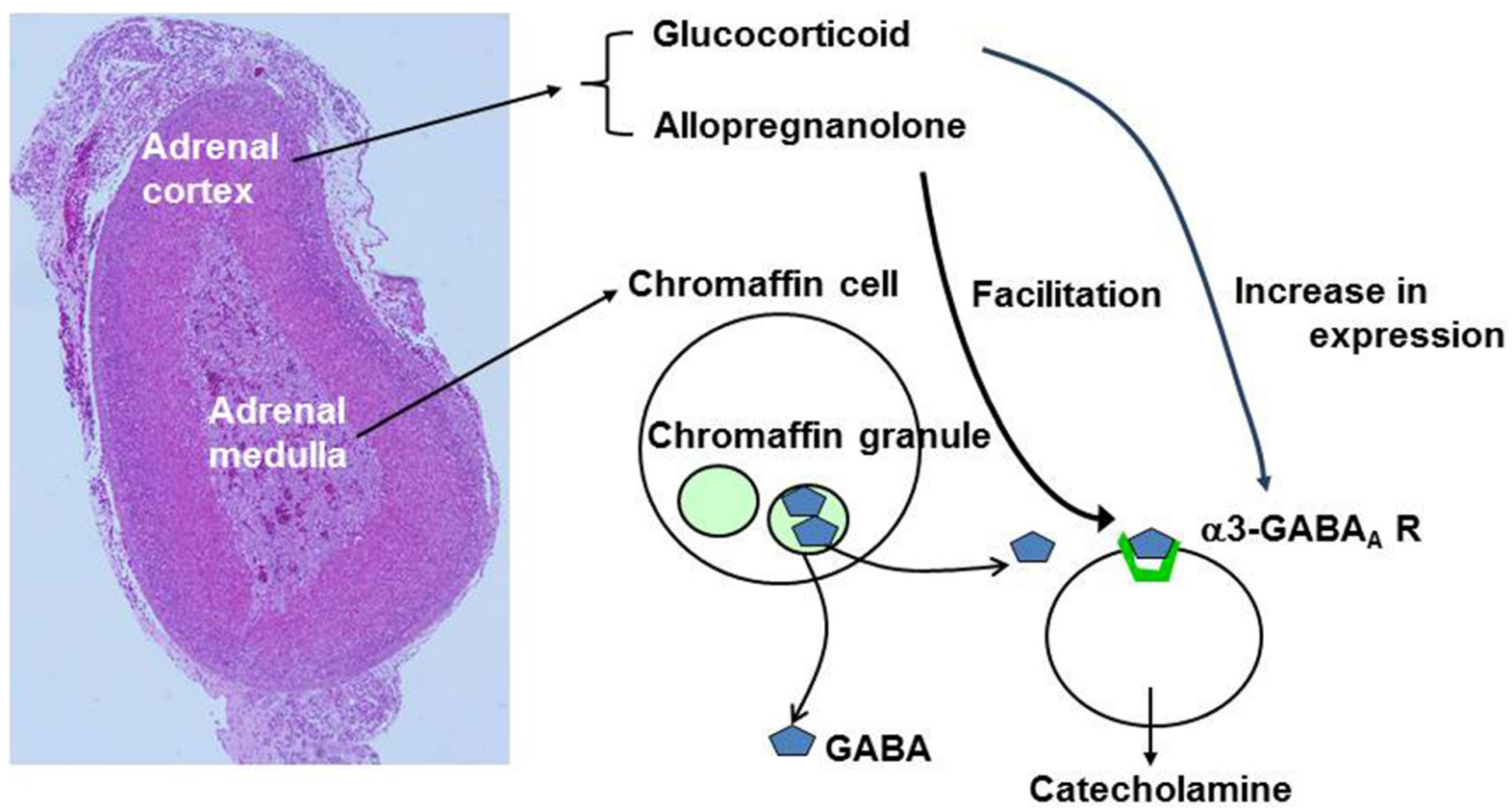

FIGURE 6 | Summary of effects of adrenal cortical hormones on GABA signaling. The left image represents hematoxylin-eosin staining of mouse adrenal gland. GABA is stored in large dense core vesicles (LDCVs) or chromaffin granules in chromaffn cells. Glucocorticoids produce an increase in expression of $\alpha 3$-containing $\mathrm{GABA}_{\mathrm{A}}$ receptors whereas allopregnanolone produces facilitation of $\mathrm{GABA}_{A}$ receptor $\mathrm{Cl}^{-} \mathrm{channel}$ activity.

humans (Genazzani et al., 1998). It is synthesized in two steps from progesterone. $5 \alpha$-reductase, which was immunologically detected in the zona fasciculata of rat adrenal glands (Yokoi et al., 1998), catalyzes the conversion from progesterone to $3 \alpha$-hydroprogesterone (DHP), which is further converted to allopregnanolone by $3 \alpha$-hydrosterone dehydrogenase.

\section{Allopregnanolone}

Exposure of guinea-pig adrenal chromaffin cells to allopregnanolone resulted in an enhancement of $\mathrm{GABA}_{\mathrm{A}}$ receptor channel activity (Inoue et al., 2013). In the presence of 0.01 and $0.1 \mu \mathrm{M}$ allopregnanolone, the amplitude of currents induced by $3 \mu \mathrm{M}$ GABA increased by 1.1 and 20 -fold (Figure 5A). In addition, the dose-response curve for steadystate GABA-induced currents was shifted toward the left and the $\mathrm{EC}_{50}$ decreased by 24 -fold in $0.1 \mu \mathrm{M}$ allopregnanolone (from $7.2 \mu \mathrm{M}$ to $0.3 \mu \mathrm{M}$; Figure 5B). This result indicates that $0.1 \mu \mathrm{M}$ GABA, which does not induce any channel activity in the absence of allopregnanolone, is able to produce a sustained current in the presence of $0.1 \mu \mathrm{M}$ allopregnanolone. The blood concentration of GABA in humans is about $0.1 \mu \mathrm{M}$ (Petty, 1994), but the concentration of GABA in the extracellular space of the adrenal medulla is not known. Since GABA is thought to be released from chromaffin cells (Kataoka et al., 1984), the concentration of GABA in the vicinity of chromaffin cells is expected to be larger than the $0.1 \mu \mathrm{M}$ concentration observed in the blood. The plasma concentration of allopregnanolone in rats has been reported to be a few nanomolar levels at rest and to be elevated to $20 \mathrm{nM}$ in stress, such as swimming (Purdy et al., 1991). However, the adrenal vein drains the venous blood from the adrenal cortex through the medulla and so it is very likely that the concentration of allopregnanolone (synthesized in the cortex) will be elevated over that in the general circulation. In light of the concentrations at which the $\mathrm{GABA}_{\mathrm{A}}$ receptor channel activity in chromaffin cells is enhanced, allopregnanolone may play an important role in modulating the para/autocrine function of GABA in adrenal medullae.

\section{DHEAS}

As explained above, DHEAS is not produced in the rat adrenal cortex and its plasma concentration is at nanomolar levels (Cutler et al., 1978). On the other hand, it is a major steroid in the human adrenal cortex and its plasma concentration is $1-10 \mu \mathrm{M}$ (Dhatariya and Nair, 2003). Therefore, DHEAS possibly has a modulatory effect on GABA signaling in the adrenal medulla of at least humans. An electrophysiological analysis of the effects of DHEAS on $\mathrm{GABA}_{\mathrm{A}}$ receptor channels in rat pituitary glands revealed that DHEAS inhibits channel activity by acting at two different sites: one is a high apparent affinity of $0.2 \mathrm{nM}$ and the other is a low apparent affinity of $15 \mu \mathrm{M}$ (Hansen et al., 1999). In guinea-pig chromaffin cells, bath application of DHEAS inhibited $\mathrm{GABA}_{\mathrm{A}}$ receptor channels in a reversible manner (unpublished observations by MI). The dose-dependent inhibition by DHEAS was well fitted with an inhibition curve with an $\mathrm{IC}_{50}$ of $3 \mu \mathrm{M}$ and a Hill's coefficient of 1 . This low potency of inhibition would negate the possible regulation of GABA signaling in the rat adrenal medulla by DHEAS. However, it might be involved in the regulation of GABA function in the human adrenal medulla. 


\section{CONCLUDING REMARKS AND PERSPECTIVE}

In many respects GABAergic transmission in the rat adrenal medulla resembles that in the developing brain. GABA is believed to be involved in the maturation process of the brain in the embryonic period, including proliferation of neurons, their trafficking, and synaptogenesis (Represa and Ben-Ari, 2005). These effects of GABA are mediated by $\mathrm{GABA}_{\mathrm{A}}$ receptormediated depolarization and the subsequent activation of voltage-dependent $\mathrm{Ca}^{2+}$ channels. $\mathrm{GABA}_{\mathrm{A}}$ receptor $\alpha$ subunits are divided into immature ( $\alpha 2$ and $\alpha 3)$ and mature $(\alpha 1)$ types; the $\alpha 2$ and $\alpha 3$ subunits are predominantly expressed in the embryonic brain and the $\alpha 3$ in adult chromaffin cells. A similar distinction is noted in GADs involved in GABA synthesis. GAD67 (immature isoform) is expressed at an early stage in brain development and in adult chromaffin cells, while GAD65 (mature isoform) expression increases in the brain during synaptogenesis. GAD65 is physically associated via palmitoylation with synaptic vesicles in the nerve terminal (Kanaani et al., 2004), whereas GAD67 is diffusely present not only in the nerve terminal, but also in the cell body. It has been suggested that in the embryonic brain GABAergic transmission, which occurs in vesicular and non-vesicular manners (Cellot and Cherubini, 2013), functions in a more general, volume transmission mode that converts to a more precise, synaptic mode with development (Represa and BenAri, 2005). In adult chromaffin cells there is no evidence for GABAergic synapses, and the isoforms for GAD and the $\mathrm{GABA}_{\mathrm{A}}$ receptor $\alpha$ subunit expressed in chromaffin cells are the immature forms. Finally, the lack of expression of plasma membrane GABA transporters (GATs; Matsuoka et al., 2008) in the adrenal gland, which are expressed in nerve terminals and glia to remove GABA from the synaptic cleft in the brain (Dalby, 2003) would enhance the ability of GABA to spread through the extracellular space. These considerations suggest that in the adrenal medulla GABA plays a para/autocrine role: it is released by chromaffin cells and acts on the same or neighboring cells to modulate catecholamine release. At least in the rat adrenal gland GABA plays a dual role. When GABA alone is applied it results in release of catecholamines. However, due to the membrane shunting effect of the chloride conductance, GABA also serves to reduce the large release elicited by volleys of nerve impulses.

\section{REFERENCES}

Asada, H., Kawamura, Y., Maruyama, K., Kume, H., Ding, R. G., Kanbara, N., et al. (1997). Cleft palate and decreased brain gamma-aminobutyric acid in mice lacking the $67-\mathrm{kDa}$ isoform of glutamic acid decarboxylase. Proc. Natl. Acad. Sci. U S A 94, 6496-6499. doi: 10.1073/pnas.94.12.6496

Barbara, J. G., and Takeda, K. (1996). Quantal release at a neuronal nicotinic synapse from rat adrenal gland. Proc. Natl. Acad. Sci. U S A 93, 9905-9909. doi: 10.1073/pnas.93.18.9905

Belelli, D., and Lambert, J. J. (2005). Neurosteroids: endogenous regulators of the GABA $_{A}$ receptor. Nat. Rev. Neurosci. 6, 565-575. doi: 10.1038/nrn1703

Ben-Ari, Y., Gaiarsa, J. L., Tyzio, R., and Khazipov, R. (2007). GABA: a pioneer transmitter that excites immature neurons and generates primitive oscillations. Physiol. Rev. 87, 1215-1284. doi: 10.1152/physrev.00017.2006
GABAergic modulation of catecholamine release is also under a second level of control by adrenal cortical cells (Figure 6). The intra-adrenal portal vascular system (Coupland, 1975) drains the cortex that secretes steroid hormones including glucocorticoids and allopregnanolone. The portal system then enters the medulla, where chromaffin cells will be exposed to the secreted hormones at high concentrations (Wurtman, 2002). Hence, increased steroid release in response to stress or other stimuli will affect GABAergic modulation of catecholamine release; glucocorticoids by possibly enhancing the expression of $\mathrm{GABA}_{\mathrm{A}}$ a3 subunit and allopregnanolone by directly potentiating responses of $\mathrm{GABA}_{\mathrm{A}}$ receptor to low concentrations of GABA. Both of these actions would enhance the ability of low levels of GABA to induce release of catecholamines. However, they would also increase the ability of GABA to reduce release induced by high frequency nerve stimulation. These effects would integrate activation of the cortical cells (perhaps reflecting stress levels) with rapid effects of released catecholamines.

The next challenge is to elucidate how the function and expression of these GABA signaling molecules are regulated to accomplish the para/autocrine function of GABA in adrenal chromaffin cells. Since adrenal chromaffin cells are exposed to adrenal cortical hormones at high concentrations through the intra-adrenal portal vascular system (Coupland, 1975), adrenal cortical hormones, such as glucocorticoids, are a first target to be investigated for their role involved in regulation and/or expression of the signaling molecules.

\section{AUTHOR CONTRIBUTIONS}

MI, KH, and YY had conception of research; KH, HM, HF, YU, $\mathrm{YY}$, and MI performed experiments; $\mathrm{KH}$ and $\mathrm{MI}$ analyzed data; MI wrote the manuscript; All the authors approved the final version of the manuscript.

\section{ACKNOWLEDGMENTS}

This study was supported by grants from Japan Society for the Promotion of Science and The Salt Science Research Foundation. We are grateful to Dr. J. H. Steinbach (Washington University, USA) for critical comments on the manuscript and Dr. T. Nakashima for hematoxylin-eosin staining of mouse adrenal gland. Thanks are also due to T. Hatama and K. Tashiro for technical assistance.

Bosman, L. W., Rosahl, T. W., and Brussaard, A. B. (2002). Neonatal development of the rat visual cortex: synaptic function of $\mathrm{GABA}_{\mathrm{A}}$ receptor $\alpha$ subunits. J. Physiol. 545, 169-181. doi: 10.1113/jphysiol.2002.026534

Caldji, C., Diorio, J., and Meaney, M. J. (2003). Variations in maternal care alter $\mathrm{GABA}_{\mathrm{A}}$ receptor subunit expression in brain regions associated with fear. Neuropsychopharmacology 28, 1950-1959. doi: 10.1038/sj.npp.1300237

Caldji, C., Tannenbaum, B., Sharma, S., Francis, D., Plotsky, P. M., and Meaney, M. J. (1998). Maternal care during infancy regulates the development of neural systems mediating the expression of fearfulness in the rat. Proc. Natl. Acad. Sci. U S A 95, 5335-5340. doi: 10.1073/pnas.95.9.5335

Castro, E., Oset-Gasque, M. J., and González, M. P. (1989). GABA A and GABA receptors are functionally active in the regulation of catecholamine secretion by bovine chromaffin cells. J. Neurosci. Res. 23, 290-296. doi: 10.1002/jnr. 490230307 
Cellot, G., and Cherubini, E. (2013). Functional role of ambient GABA in refining neuronal circuits early in postnatal development. Front. Neural Circuits 7:136. doi: 10.3389/fncir.2013.00136

Chen, J., Evans, A. N., Liu, Y., Honda, M., Saavedra, J. M., and Aguilera, G. (2012). Maternal deprivation in rats is associated with cortricotropin releasing hormone $(\mathrm{CRH})$ promoter hypomethylation and enhances $\mathrm{CRH}$ transcriptional responses to stress in adulthood. J. Neuroendocrinol. 24, 1055-1064. doi: 10.1111/j.1365-2826.2012.02306.x

Corpéchot, C., Young, J., Calvel, M., Wehrey, C., Veltz, J. N., Touyer, G., et al. (1993). Neurosteroids: $3 \alpha$-hydroxy-5 $\alpha$-pregnan-20-one and its precursors in the brain, plasma and steroidogenic glands of male and female rats. Endocrinology 133, 1003-1009. doi: 10.1210/en.133.3.1003

Coupland, R. E. (1975). "Blood supply of the adrenal gland," in Handbook of Physiology Section 7 Endocrinology, Vol 6 Adrenal Gland, eds H. Blaschko, G. Sayers, and A. D. Smith (Washington, DC: American Physiological Society), 283-294.

Coupland, R. E., Parker, T. L., Kesse, W. K., and Mohamed, A. A. (1989). The innervation of the adrenal gland. III. Vagal innervation. J. Anat. 163, 173-181.

Cutler, G. B. Jr., Glenn, M., Bush, M., Hodgen, G. D., Graham, C. E., and Loriaux, D. L. (1978). Adrenarche: a surey of rodents, domestic animals and primates. Endocrinology 103, 2112-2118. doi: 10.1210/endo-103-6-2112

Dalby, N. O. (2003). Inhibition of gamma-aminobutyric acid uptake: anatomy, physiology and effects against epileptic seizures. Eur. J. Pharmacol. 479, 127-137. doi: 10.1016/j.ejphar.2003.08.063

Davis, J. P., Chipperfield, A. R., and Harper, A. A. (1993). Accumulation of intracellular chloride by $(\mathrm{Na}-\mathrm{K}-\mathrm{Cl})$ co-transport in rat arterial smooth muscle is enhanced in deoxycorticosterone acetate (DOCA)/salt hypertension. J. Mol. Cell. Cardiol. 25, 233-237. doi: 10.1006/jmcc.1993.1029

de Kloet, E. R., Joëls, M., and Holsboer, F. (2005). Stress and the brain: from adaptation to disease. Nat. Rev. Neurosci. 6, 463-475. doi: 10.1038/nrn1683

Dhatariya, K. K., and Nair, K. S. (2003). Dehydroepiandrosteone: is there a role for replacement? Mayo Clin. Proc. 78, 1257-1273. doi: 10.4065/78. 10.1257

Ding, B., Frisina, R. D., Zhu, X., Sakai, Y., Sokolowski, B., and Walton, J. P. (2014). Direct control of $\mathrm{Na}^{+}-\mathrm{K}^{+}-2 \mathrm{Cl}^{-}$-contransport protein (NKCC1) expression with aldosterone. Am. J. Physiol. Cell Physiol. 306, C66-C75. doi: 10. 1152/ajpcell.00096.2013

Ehrlich, D. E., Ryan, S. J., Hazra, R., Guo, J. D., and Rainnie, D. G. (2013). Postnatal maturation of GABAergic transmission in the rat basolateral amygdala. J. Neurophysiol. 110, 926-941. doi: 10.1152/jn.01105.2012

Gammelsaeter, R., Frøyland, M., Aragón, C., Danbolt, N. C., Fortin, D., StormMathisen, J., et al. (2004). Glycine, GABA and their transporters in pancreatic islets of langerhans: evidence for a paracrine transmitter interplay. J. Cell Sci. 117, 3749-3758. doi: 10.1242/jcs.01209

Genazzani, A. R., Petraglia, F., Bernardi, F., Casarosa, E., Salvestroni, C., Tonetti, A., et al. (1998). Circulating levels of allopregnanolone in humans: gender, age and endocrine influences. J. Clin. Endocrinol. Metab. 83, 2099-2103. doi: 10.1210/jc.83.6.2099

Geppert, M., Goda, Y., Hammer, R. E., Li, C., Rosahl, T. W., Stevens, C. F., et al. (1994). Synaptotagmin I: a major $\mathrm{Ca}^{2+}$ sensor for transmitter release at a central synapse. Cell 79, 717-727. doi: 10.1016/0092-8674(94) 90556-8

Goto, J., Otsuka, F., Yamashita, M., Suzuki, J., Otani, H., Takahashi, H., et al. (2009). Enhancement of aldosterone-induced catecholamine production by bone morphogenetic protein-4 through activating rho and SAPK/JNK pathway in adrenomedullar cells. Am. J. Physiol. Endocrinol. Metab. 296, E904-E916. doi: 10.1152/ajpendo.90840.2008

Greif, K. F., Tillakaratne, N. J., Erlander, M. G., Feldblum, S., and Tobin, A. J. (1992). Transient increase in expression of a glutamate decarboxylase (GAD) mRNA during the postnatal development of the rat striatum. Dev. Biol. 153, 158-164. doi: 10.1016/0012-1606(92)90100-u

Hansen, S. L., Fjalland, B., and Jackson, M. B. (1999). Differential blockade of gamma-aminobutyric acid type A receptors by the neuroactive steroid dehydroepiandrosterone sulfate in posterior and intermediate pituitary. Mol. Pharmacol. 55, 489-496.

Harada, K., Matsuoka, H., Miyata, H., Matsui, M., and Inoue, M. (2015). Identification of muscarinic receptor subtypes involved in catecholamine secretion in adrenal medullary chromaffin cells by genetic deletion. Br. J. Pharmacol. 172, 1348-1359. doi: 10.1111/bph.13011

Harada, K., Matsuoka, H., Nakamura, J., Fukuda, M., and Inoue, M. (2010). Storage of GABA in chromaffin granules and not in synaptic-like microvesicles in rat adrenal medullary cells. J. Neurochem. 114, 617-626. doi: 10.1111/j.14714159.2010.06792.x

Hui, E., Bai, J., Wang, P., Sugimori, M., Llinas, R. R., and Chapman, E. R. (2005). Three distinct kinetic groupings of the synaptotagmin family: candidate sensors for rapid and delayed exocytosis. Proc. Natl. Acad. Sci. U S A 102, 5210-5214. doi: 10.1073/pnas.0500941102

Inoue, M., Harada, K., Matsuoka, H., and Warashina, A. (2010). Paracrine role of GABA in adrenal chromaffin cells. Cell. Mol. Neurobiol. 30, 1217-1224. doi: 10. 1007/s10571-010-9569-x

Inoue, M., Harada, K., Nakamura, J., and Matsuoka, H. (2013). Regulation of alpha3-containing $\mathrm{GABA}_{\mathrm{A}}$ receptors in guinea-pig adrenal medullary cells by adrenal steroids. Neuroscience 253, 245-255. doi: 10.1016/j.neuroscience.2013. 08.046

Inoue, M., Matsuo, T., and Ogata, N. (1985). Possible involvement of $\mathrm{K}^{+}$conductance in the action of gamma-aminobutyric acid in the guinea-pig hippocampus. Br. J. Pharmacol. 86, 515-524. doi: 10.1111/j.1476-5381.1985. tb08923.x

Iwasa, K., Oomori, Y., and Tanaka, H. (1998). Gamma aminobutyric acid immunoreactivity in the mouse adrenal gland during postnatal development. Arch. Histol. Cytol. 61, 373-382. doi: 10.1679/aohc.61.373

Johnston, D., and Wu, S. M.-S. (1995). Foundations of Cellular Neurophysiology. Cambridge, MA: MIT Press.

Kaila, K., Price, T. J., Payne, J. A., Puskarjov, M., and Voipio, J. (2014). Cationchloride contransporters in neuronal development, plasticity and disease. Nat. Rev. Neurosci. 15, 637-654. doi: 10.1038/nrn3819

Kajiwara, R., Sand, O., Kidokoro, Y., Barish, M. E., and Iijima, T. (1997). Functional organization of chromaffin cells and cholinergic synaptic transmission in rat adrenal medulla. Jpn. J. Physiol. 47, 449-464. doi: 10. 2170/jjphysiol.47.449

Kanaani, J., Diacovo, M. J., El-Husseini, A.-D., Bredt, D. S., and Baekkeskov, S. (2004). Palmitoylation controls trafficking of GAD65 from Golgi membranes to axon-specific endosomes and a Rab5a-dependent pathway to presynaptic clusters. J. Cell Sci. 117, 2001-2013. doi: 10.1242/jcs.01030

Kasai, H. (1999). Comparative biology of $\mathrm{Ca}^{2+}$-dependent exocytosis: implications of kinetic diversity for secretory function. Trends Neurosci. 22, 88-93. doi: 10.1016/s0166-2236(98)01293-4

Kataoka, Y., Fujimoto, M., Alho, H., Guidotti, A., Geffard, M., Kelly, G. D., et al. (1986). Intrinsic gamma aminobutyric acid receptors modulate the release of catecholamine from canine adrenal gland in situ. J. Pharmacol. Exp. Ther. 239, 584-590.

Kataoka, Y., Gutman, Y., Guidotti, A., Panula, P., Wroblewski, J., CosenzaMurphy, D., et al. (1984). Intrinsic GABAergic system of adrenal chromaffin cells. Proc. Natl. Acad. Sci. U S A 81, 3218-3222. doi: 10.1073/pnas.81.10.3218

Lambert, J. J., Belelli, D., Hill-Venning, C., and Peters, J. A. (1995). Neurosteroids and $\mathrm{GABA}_{\mathrm{A}}$ receptor function. Trends Pharmacol. Sci. 16, 295-303. doi: 10. 1016/S0165-6147(00)89058-6

Laurie, D. J., Wisden, W., and Seeburg, P. H. (1992). The distribution of thirteen GABAA receptor subunit mRNAs in the rat brain. III. embryonic and postnatal development. J. Neurosci. 12, 4151-4172.

Le Goascogne, C., Sananès, N., Gouézou, M., Takemori, S., Kominami, S., Baulieu, E. E., et al. (1991). Immunoreactive cytochrome P-450(17 $\alpha)$ in rat and guinea-pig gonads, adrenal glands and brain. J. Reprod. Fertil. 93, 609-622. doi: 10.1530/jrf.0.0930609

Mahgoub, A., Hirsch, P. F., and Munson, P. L. (1997). Calcium-lowering action of glucocorticoids in adrenalectomized-prarathyroidectomized rats. Specificity and relative potency of natural and synthetic glucocorticoids. Endocine 6, 279-283. doi: 10.1007/bf02820504

Matsuoka, H., Harada, K., Endo, Y., Waraahina, A., Doi, Y., Nakamura, J., et al. (2008). Molecular mechanisms supporting a raracrinel role of GABA in rat adrenal medullary cells. J. Physiol. 586, 4825-4842. doi: 10.1113/jphysiol.2008. 158709

Matsuoka, H., Harada, K., Nakamura, J., Fukuda, M., and Inoue, M. (2011). Differential distribution of synaptotagmin-1, $-4,-7$ and -9 in rat adrenal chromaffin cells. Cell Tissue Res. 344, 41-50. doi: 10.1007/s00441-011-1131-8 
Minneci, F., Kanichay, R. T., and Silver, R. A. (2011). Estimation of the time course of neurotransmitter release at central synapses from the first latency of postsynaptic currents. J. Neurosci. Methods 205, 49-64. doi: 10.1016/j. jneumeth.2011.12.015

Mohamed, A. A., Parker, T. L., and Coupland, R. E. (1988). The innervation of the adrenal gland. II. the source of spinal afferent nerve fibres to the guinea-pig adrenal gland. J. Anat. 160, 51-58.

Mozrzymas, J. W., Barberis, A., and Vicini, S. (2007). GABAergic currents in RT and VB thalamic nuclei follow kinetic pattern of $\alpha 3$ - and $\alpha 1$-subunit-containing GABA $_{A}$ receptors. Eur. J. Neurosci. 26, 657-665. doi: 10.1111/j.1460-9568.2007. 05693.x

Navone, F., Jahn, R., Di Gioia, G., Stukenbrok, H., Greengard, P., and De Camilli, P. (1986). Protein p38: an integral membrane protein specific for small vesicles of neurons and neuroendocrine cells. J. Cell Biol. 103, 2511-2527. doi: $10.1083 /$ jcb.103.6.2511

Obata, K. (2013). Synaptic inhibition and gamma-aminobutyric acid in the mammalian central nervous system. Proc. Jpn. Acad. Ser. B Phys. Biol. Sci. 89, 139-156. doi: 10.2183/pjab.89.139

Okada, M., Onodera, K., Van Renterghem, C., Sieghart, W., and Takahashi, T. (2000). Functional correlation of $\mathrm{GABA}_{\mathrm{A}}$ receptor $\alpha$ subunits expression with the properties of IPSCs in the developing thalamus. J. Neurosci. 20, 2202-2208.

Okada, Y., Taniguchi, H., and Schimada, C. (1976). High concentration of GABA and high glutamate decarboxylase activity in rat pancreatic islets and human insulinoma. Science 194, 620-622. doi: 10.1126/science.185693

Ortinski, P. I., Lu, C., Takagaki, K., Fu, Z., and Vicini, S. (2004). Expression of distrinct $\alpha$ subunits of $\mathrm{GABA}_{\mathrm{A}}$ receptor regulates inhibitory synaptic strength. J. Neurophysiol. 92, 1718-1727. doi: 10.1152/jn.00243.2004

Pallotto, M., and Deprez, F. (2014). Regulation of adult neurogenesis by GABAergic transmission: signaling beyond $\mathrm{GABA}_{\mathrm{A}}$-receptors. Front. Cell. Neurosci. 8:166. doi: 10.3389/fncel.2014.00166

Park-Chung, M., Malayev, A., Purdy, R. H., Gibbs, T. T., and Farb, D. H. (1999). Sulfated and unsulfated steroids modulate $\gamma$-aminobutyric $\operatorname{acid}_{A}$ receptor function through distinct sites. Brain Res. 830, 72-87. doi: 10.1016/s00068993(99)01381-5

Peters, J. A., Lambert, J. J., and Cottrell, G. A. (1989). An electrophysiological investigation of the characteristics and function of $\mathrm{GABA}_{\mathrm{A}}$ receptors on bovine adrenomedullary chromaffin cells. Pflugers Arch. 415, 95-103. doi: 10. 1007/bf00373146

Petty, F. (1994). Plasma concentrations of gamma-aminobutyric acid (GABA) and mood disorders: a blood test for manic depressive disease? Clin. Chem. 40, 296-302.

Pinal, C. S., and Tobin, A. J. (1998). Uniqueness and redundancy in GABA production. Perspect. Dev. Neurobiol. 5, 109-118.

Plattner, H., Artalejo, A. R., and Neher, E. (1997). Ultrastructural organization of bovine chromaffin cell cortex-analysis by cryofixation and morphometry of aspects pertinent to exocytosis. J. Cell Biol. 139, 1709-1717. doi: 10.1083/jcb. 139.7.1709

Purdy, R. H., Morrow, A. L., Moore, P. H. Jr., and Paul, S. M. (1991). Stressinduced elevations of $\gamma$-induced elevations of aminobutyric acid type A receptor-active steroids in the rat brain. Proc. Natl. Acad. Sci. U S A 88, 4553-4557. doi: 10.1073/pnas.88.10.4553

Reddy, D. S., and Rogawski, M. A. (2002). Stress-induced deoxycorticosteronederived neurosteroids modulate $\mathrm{GABA}_{\mathrm{A}}$ receptor function and seizure susceptibility. J. Neurosci. 22, 3795-3805.

Reetz, A., Solimena, M., Matteoli, M., Folli, F., Takei, K., and De Camilli, P. (1991). GABA and pancreatic beta-cells: colocalization of glutamic acid decarboxylase (GAD) and GABA with synaptic-like microvesicles suggests their role in GABA storage and secretion. Embo J. 10, 1275-1284.

Represa, A., and Ben-Ari, Y. (2005). Trophic actions of GABA on neuronal development. Trends Neurosci. 28, 278-283. doi: 10.1016/j.tins.2005.03.010

Reul, J. M., de Kloet, E. R., van Sluijs, F. J., Rijnberk, A., and Rothuizen, J. (1990). Binding characteristics of mineralocorticoid and glucocorticoid receptors in dog brain and pituitary. Endocrinology 127, 907-915. doi: 10.1210/endo-1272-907

Rorsman, P., Berggren, P. O., Bokvist, K., Ericson, H., Möhler, H., Ostenson, C. G., et al. (1989). Glucose-inhibition of glucagon secretion involves activation of GABAA-receptor chloride channels. Nature 341, 233-236. doi: 10. 1038/341233a0

Rudolph, U., and Knoflach, F. (2011). Beyond classical benzodiazepines: novel therapeutic potential of $\mathrm{GABA}_{\mathrm{A}}$ receptor subtypes. Nat. Rev. Drug Discov. 10, 685-697. doi: 10.1038/nrd3502

Sapolsky, R. M., and Meaney, M. J. (1986). Maturation of the adrenocortical stress response: neuroendocrine control mechanisms and the stress hyporesponsive period. Brain Res. 396, 64-76. doi: 10.1016/0165-0173(86) 90010-x

Serafini, R., Maric, D., Maric, I., Ma, W., Fritschy, J. M., Zhang, L., et al. (1998). Dominant GABAA receptor/Cl- channel kinetics correlate with the relative expressions of $\alpha 2, \alpha 3, \alpha 5$ and $\beta 3$ subunits in embryonic rat neurones. Eur. J. Neurosci. 10, 334-349. doi: 10.1046/j.1460-9568.1998. 00022.x

Soghomonian, J. J., and Martin, D. L. (1998). Two isoforms of glutamate decarboxylase: why? Trends Pharmacol. Sci. 19, 500-505. doi: 10.1016/s01656147(98)01270-x

Stork, O., Ji, F. Y., Kaneko, K., Stork, S., Yoshinobu, Y., Moriya, T., et al. (2000). Postnatal development of a GABA deficit and disturbance of neural functions in mice lacking GAD65. Brain Res. 865, 45-58. doi: 10.1016/s00068993(00)02206-x

Succol, F., Fiumelli, H., Benfenati, F., Cancedda, L., and Barberis, A. (2012). Intracellular chloride concentration influences the $\mathrm{GABA}_{\mathrm{A}}$ receptor subunit composition. Nat. Commun. 3:738. doi: 10.1038/ncomms1744

Thomas-Reetz, A. C., and De Camilli, P. (1994). A role for synaptic vesicles in non-neuronal cells: clues from pancreatic beta cells and from chromaffin cells. FASEB J. 8, 209-216.

Ulmann, A., Bertagna, C., Le Go, A., Husson, J. M., Tache, A., Sassano, P., et al. (1985). Assessment of the antimineralocorticoid effect of RU 28318 in healthy men with induced exogenous and endogenous hypermineralocorticism. Eur. J. Clin. Pharmacol. 28, 531-535. doi: 10.1007/bf00544063

Wang, P., Chicka, M. C., Bhalla, A., Richards, D. A., and Chapman, E. R. (2005). Synaptotagmin VII is targeted to secretory organelles in PC12 cells, where it functions as a high-affinity calcium sensor. Mol. Cell. Biol. 25, 8693-8702. doi: $10.1128 / \mathrm{mcb} .25 .19 .8693-8702.2005$

Warashina, A., and Inoue, M. (2012). $\mathrm{Ca}^{2+}$ imaging in perfused adrenal medullae. J. UOEH 34, 163-173. doi: 10.7888/juoeh.34.163

Wurtman, R. J. (2002). Stress and the adrenocortical control of epinephrine synthesis. Metab. Clin. Exp. 51, 11-14. doi: 10.1053/meta.2002.33185

Xie, Z., Currie, K. P., Cahill, A. L., and Fox, A. P. (2003). Role of cl- co-transporters in the excitation produced by GABAA receptors in juvenile bovine adrenal chromaffin cells. J. Neurophysiol. 90, 3828-3837. doi: 10.1152/jn.00617.2003

Xu, E., Kumar, M., Zhang, Y., Ju, W., Obata, T., Zhang, N., et al. (2006). Intra-islet insulin suppresses glucagon release via $\mathrm{GABA}_{-} \mathrm{GABA}_{\mathrm{A}}$ receptor system. Cell Metab. 3, 47-58. doi: 10.1016/j.cmet.2005.11.015

Yokoi, H., Tsuruo, Y., Miyamoto, T., and Ishimura, K. (1998). Steroid $5 \alpha$-reductase type 1 immunolocalized in the adrenal gland of normal, gonadectomized and sex hormone-supplemented rats. Histochem. Cell Biol. 109, 127-134. doi: 10.1007/s004180050210

Zhu, W. J., and Vicini, S. (1997). Neurosteroid prolongs GABA A channel deactivation by altering kinetics of desensitized states. J. Neurosci. 17, 4022-4031.

Ziegler, M. G., Elayan, H., Milic, M., Sun, P., and Gharaibeh, M. (2012). Epinephrine and the metabolic syndrome. Curr. Hypertens. Rep. 14, 1-7. doi: 10.1007/s11906-011-0243-6

Conflict of Interest Statement: The authors declare that the research was conducted in the absence of any commercial or financial relationships that could be construed as a potential conflict of interest.

Copyright (c) 2016 Harada, Matsuoka, Fujihara, Ueta, Yanagawa and Inoue. This is an open-access article distributed under the terms of the Creative Commons Attribution License (CC BY). The use, distribution and reproduction in other forums is permitted, provided the original author(s) or licensor are credited and that the original publication in this journal is cited, in accordance with accepted academic practice. No use, distribution or reproduction is permitted which does not comply with these terms. 